\title{
Soil, bark and leaf trace metal loads related to the war legacy (The Prašnik rainforest, Croatia)
}

The Mining-Geology-Petroleum Engineering Bulletin UDC: 504

DOI: $10.17794 /$ rgn.2016.2.2

Original scientific paper

\author{
*Ivana Mesić Kišs,2; Bojan Karaica3; Gordana Medunić²; Marija Romićc; Jasenka Šabarić5; Dražen Balen²; \\ Kristijan Šoštarko \\ ${ }^{1}$ ES kralja Tomislava, Ulica Matice hrvatske 1, 31500 Našice \\ ${ }^{2}$ University of Zagreb, Faculty of Science, Department of Geology, Horvatovac 95, Zagreb, 10 000, Croatia \\ ${ }^{3}$ Hyla - Croatian Herpetological Society, Lipovac I 7, Zagreb, 10 000, Croatia \\ ${ }^{4}$ University of Zagreb, Faculty of Agriculture, Svetošimunska 25, Zagreb, 10 000, Croatia \\ ${ }^{5}$ School of Medicine University of Zagreb, Andrija Štampar School of public health, Rockfellerova 4, Zagreb, 10 000, Croatia
}

\begin{abstract}
As a special forest vegetation reserve, the Prašnik rainforest is a highly protected area which owes its protection not only to a unique composition of trees, but also to its geographical position and, to an extent, historical events. It is situated on the Sava River left bank, north of the city of Stara Gradiška (cca. $3 \mathrm{~km}$ ). The study area belongs to the southwestern part of the Pannonian Basin, specifically the Sava Depression. The aim of this study was to assess the possible impact of war activities in Croatia (23 years ago) when numerous mines were laid in this region and to establish the major and trace metal baseline concentrations for future investigations. Ten topsoil (S) samples were taken randomly with adjacent vegetation (bark and leaves) at each site. Major and trace metal concentrations were measured for all three types of samples using the ICP method. Analysed soils are composed of quartz, micaceous mineral, $14 \AA$ mineral, plagioclase and mixed layer minerals. All metal values in the sample taken from an ex-mine crater are 2-4 times higher compared to other. Generally, positive statistically significant Kendall's Tau correlation coefficients of trace metals ( $\mathrm{Cd}, \mathrm{Cr}, \mathrm{Cu}, \mathrm{Ni}$, and $\mathrm{Zn}$ ) were found for all combinations of the S (soil), B (bark), and L (leaf) groups. Such results indicate that the war activity have played a certain role in the distribution pattern of soil as well as vegetative trace metal levels.
\end{abstract}

\section{Keywords}

major metals, trace metals, war, protected area, Prašnik

\section{Introduction}

The expansion of industrial, mining and war activities, rapid growth of population as well as other reasons, have caused extensive trace metal contamination of the environment because they are continuously being added to soil, waterways and surrounding atmosphere (Aksoy et al. 2000; Ernst 1990, 1995; Stanišić et al. 2012, Lucaciu et al., 1999). Military activities such as shelling and use of landmines raise major concerns regarding the possible major and trace metal enrichment in soils (Chappell et al., 2011). The Prašnik special rainforest reserve is an area where such enrichment/contamination could have occurred during the 1990's war when this area was covered with landmines.

This area has been excluded from human exploitation activities since 1928 and the only human influence on this protected area could have come via natural pathways (e.g. air or water). Direct anthropogenic impact on the area of the Prašnik rainforest is thus limited to these means of transport. The Prašnik rainforest is one of the areas for which the existence and impact of regional air and water pollution could be revealed because of its status as a highly protected area of great biological importance and its exclusion from direct human influence..

Soils are the resorvoir for elemental and biological harmful constituents, including trace metals (Zimmerman \& Weindorf, 2010). When reaching excessive levels, they can compromise the soil's function, causing toxicity to plants, 
animals and humans (Kim \& Kim, 1999). Toxic trace metals such as $\mathrm{Cd}$, $\mathrm{Hg}$ and $\mathrm{Pb}$, are first accumulated in the soil and reach the plants through the roots. Some metals, such as $\mathrm{Cd}$ can easily remobilize from the soil, whereas $\mathrm{Pb}$ or $\mathrm{Hg}$ are rather firmly bound to colloids in the soil. Various anthropogenic activities (e.g. industrial facilities, urban and highway traffic, etc.) have a great potential to considerably affect the natural levels of major and trace metals in soils and plants (Sawidis et al., 2011; Vidosavljević et al., 2014; De Nicola et al., 2008, 2013; Fantozzi et al., 2013). Furthermore, trace metals can also be found in the parent material from which the soil is developed. Soil properties, like $\mathrm{pH}$, redox-potential, and the existence of different organic and inorganic reactants, can modify metal mobility (Romić, 2012).

The most sensitive part of the forest ecosystem is mycorrhiza which is directly affected by metal contamination (Godbold et al., 1987). Furthermore, the increase of metal concentration in soil can indirectly influence the biomass production, the decomposition of leaves (the creation of leaf mulch) and the activity of enzymes (Vrbek \& Pilaš, 2004) thus destabilizing the natural balance of the forest ecosystem. Investigation by Matić et al. (1979) defined the number of tree species present in the Prašnik rainforest: 1487 penducled old oak trees (Quercus robur L.), 48 common hornbeam (Carpinus betulus L.) and beech trees (Fagus sylvatica L.). Although there are numerous biomonitoring studies which include different plant species, there are very few which involve pedunculate oak (Quercus robur L.) as a biomonitoring plant. Vidosavljević et al. (2014) investigated the content of trace metals in soil, water, plants and humans after the 1990's war in Croatia. Trace metal content in the soils were investigated in the northwestern part of the country (Vrbek \& Pilaš, 2004) for the same type of biocenosis (Quercus robur and Carpino betuli) but did not include vegetation material and were focused only on $\mathrm{Pb}, \mathrm{Zn}$ and $\mathrm{Cu}$. Mesić et al. (2014) made a brief assessment of soil and vegetation polution due to war activities for the area of the special forest reserve Prašnik, but there was no major study of major and trace metal content in soil and the adjacent vegetation.

Landmines are made of metal, timber or plastic. They also contain additional compounds including $\mathrm{Cd}, \mathrm{Cr}, \mathrm{Cu}, \mathrm{Fe}, \mathrm{Mn}$, $\mathrm{Ni}, \mathrm{Pb}, \mathrm{Zn}$, and $\mathrm{Hg}$, of which $\mathrm{Fe}, \mathrm{Mn}, \mathrm{Zn}, \mathrm{Cu}$ and $\mathrm{Ni}$ are essential micronutrients in the plant-soil system (Berhe, 2007). This paper aims to investigate the possible influence of landmine explosion on selected major and trace metal concentrations in soil (S) and the adjacent vegetation (bark (B) and leaf (L)) and to establish the baseline concentrations of the aforementioned metals for the area of the Prašnik special forest reserve.

It is important to screen for potential metal deficiency because of its natural significance or the excess of potentially toxic metals. As some metals are nutrients, their deficiency can destabilize the natural balance of the forest ecosystem by reducing plant growth and eventually lead to the loss of plant species. The same scenario plays out with the high content of certain metals (Kabata-Pendias, 2011).

\section{Study area}

The Prašnik rainforest is geographically divided into the North and South Prašnik area and both are out of limits for visitors since the war in 1990's because of landmine presence. The forest is a unique phytocenosis, protected as a special forest vegetation reserve since 1965, and is the last remnant of the Slavonian rainforest. With its 58 hectares of surface, the Prašnik rainforest is located north of the Stara Gradiška city, near the Sava River left bank (cca. $0.5 \mathrm{~km}$ ) at an altitude of $96 \mathrm{~m}$ (see Figure 1). 


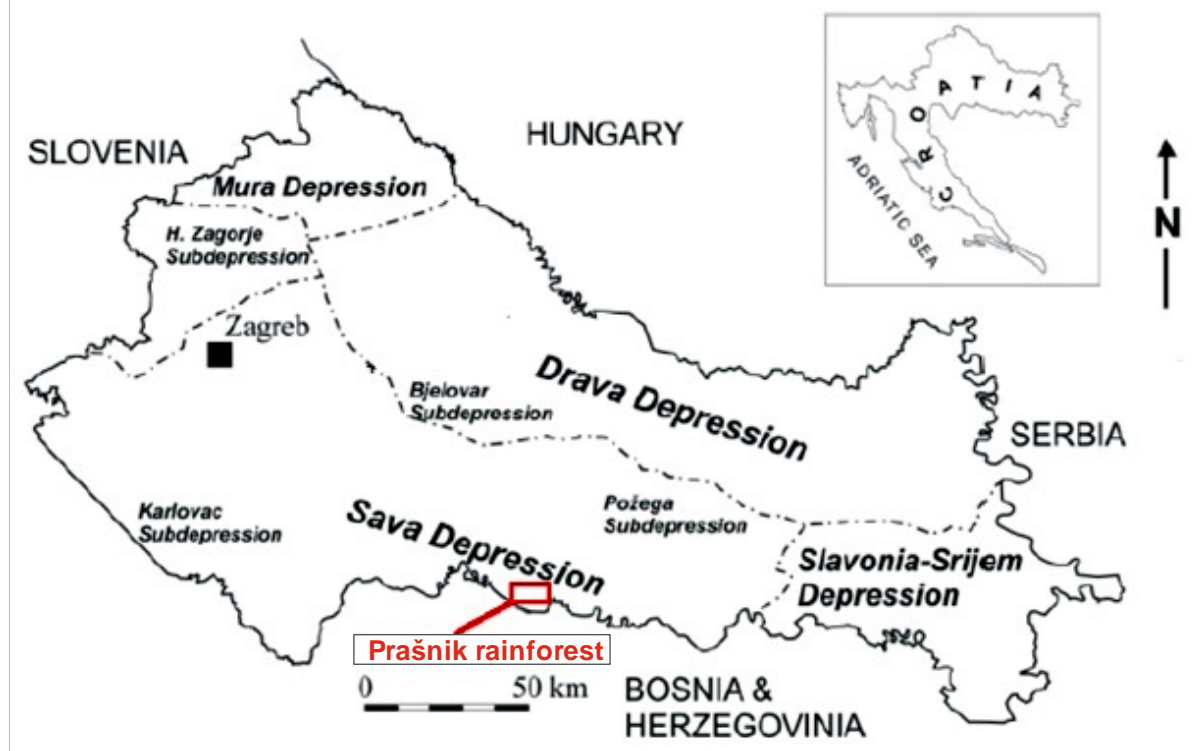

Figure 1: Geographic location of the Prašnik rainforest (modified after Balić et al., 2oo8)

The sampling area is located cca. 250-300 m north of the village of Novi Varoš in the North Prašnik area. The forest is enclosed from the north side by the A3 state highway (сca. $2.5 \mathrm{~km}$ ) and in the south (сca. $3.5 \mathrm{~km}$ ) by the water channel of the Sloboština stream, which connects to the Sava River. The northwest, north, northeast and south borders of the Prašnik rainforest are in the near proximity of agricultural areas. They are separated from the rainforest by roads, low vegetation areas and the Sloboština stream channel.

\subsection{Geological setting}

The Prašnik rainforest is located in the southwestern part of Pannonian Basin System (PBS) (Figure 1), specifically a tectonic unit (sub-basin) known as the Sava Depression (Šparica et al., 1984). On its way from the source, the Sava River comes in contact with different sediments and sedimentary rocks which are predominantly composed of Mesozoic limestone and dolomite and subordinately with Paleozoic metamorphic rocks and clastites and Paleogene clastites (Buser et al., 1989).

The Sava Depression represents the southern border of the PBS. It is mainly composed of PB sedimentary rocks together with the Sava River alluvial and Quaternary siliciclastic sediments. Beneath sedimentary rocks is a crystalline basement. The Prašnik rainforest area of the Sava depression is covered with thick Quaternary alluvial deposits which

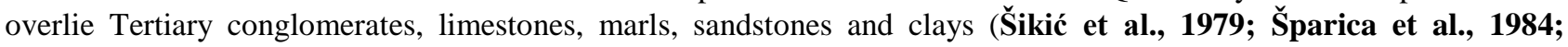
Halamić \& Miko, 2009).

The surface of the study area is covered with lacustrine-marshy and Quaternary sands, silts and clays where Pseudogley deposits, also known as carbonate-reduced loess, are a dominant lithological unit. These two deposits can be considered, for the most part, as lateral equivalents even though lacustrine-marshy deposits begin to form closer to Middle Pleistocene and its lateral equivalent deposits date from the Lower Pleistocene to Lower Holocene. Lacustrine-marshy deposits, which have very low organic matter content, are dominantly composed of silty sand (muddy sand), sand and subordinately of silty clay. Very thin (max. $3 \mathrm{~m}$ thick) marshy Holocene deposits and overly lacustrine-marshy deposits are mainly composed of silt, silty sand (muddy sand), illite clay, fine sand and small lenses of gravel. They cover relatively small areas around the Prašnik rainforest and are more prominent to the southeast and east along the river Sava. They formed as a result of groundwater level rising in the marshy areas where gradual subsidence made local depressions. The youngest deposits closest to the Prašnik rainforest can be found $500 \mathrm{~m}$ south from the area known as South Prašnik and are composed of sand, silty sand (muddy sand) and gravelly sand. These sediments are a result of the Sava River's and Vrbas River's occasional flooding (Šparica et al., 1984).

Pseudogley soil type dominates the study area covering a significant area of the Pannonian part of Croatia and is mostly found at Pleistocene terraces (Bašić, 2013). 


\subsection{Pedological setting}

The Sava River occasionally floods these areas during high water stands thus building the alluvial plain. According to Bogunović et al. (1998), hydromorphic soils such as Fluvisols, Gleysols and Podzoluvisols prevail in area of Prašnik rainforest (see Figure 2).

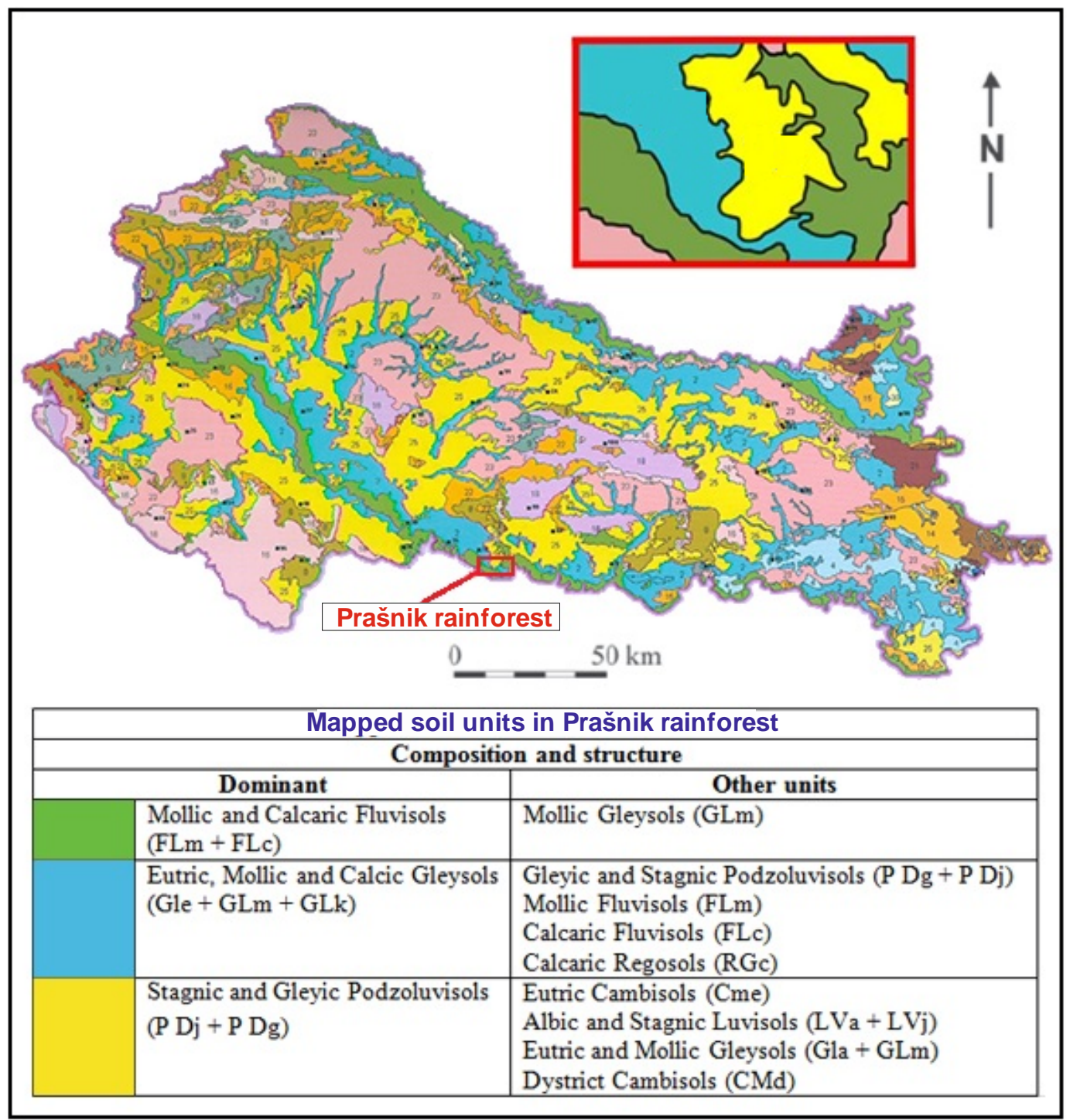

Figure 2: Eastern Croatia soil map with defined soil types of Prašnik rainforest area (modified after Bogunović et al., 1998)

Soil types for the studied area are classified as Pseudogley (Pseudogley-Gley, Luvisol, Eugley, Humogley) and the east part of the North Prašnik area is covered by Eugley (Gley soil, Histosol) soil type according to the pedological map for the Republic of Croatia and the World reference base for soil resources (Bogunović et al., 1998). The South Prašnik area is covered with partially hydromeliorated Eugley (Humofluvisol, Humogley) soil. Pseudogley occupies $10.5 \%$ of the total land territory of Croatia (Bašić, 2013; Halamić \& Miko, 2009) and is classified as hydromorphic soil which is excessively wetted by precipitation, flooding and underground waters. These soils are saturated with water causing hydromorphism (Husnjak, 2014). Hydromorphic soils, which dominate the Croatian part of the Pannonian lowlands (Halamić \& Miko, 2009; Husnjak, 2014) and wide areas along the major Pannonian lowland rivers (Sava, Mura, Drava and Danube) are covered with alluvial and Eugley soils which can be also found in the study area.

\section{Materials and methods}


Ten topsoil (S) samples (depth 10-20 cm) were collected randomly within a radius of $20 \mathrm{~m}$ in the North Prašnik area ( $45^{\circ} 12^{\prime} 25^{\prime}$ ' N, $17^{\circ} 12^{\prime} 38^{\prime \prime}$ E), immediately behind the danger mine sign. At each site, adjacent vegetation, i.e. bark (B) and leaves (L), were sampled as well.

Mineral content was obtained on two samples (S-6 and S-9) by Philips X'pert difractometer using $\mathrm{Cu} \mathrm{K} \alpha$ radiation. Measurements were made using a continuous scan operated at $40 \mathrm{kV}$ and $32 \mathrm{~mA}$ with a speed of $0.02^{\circ} 2 \theta / \mathrm{s}$. The sample was randomly oriented powder.

Soil samples were air-dried and sieved. Grain size fraction $<0.5 \mathrm{~mm}$ was analysed. For the determination of soil physical and chemical characteristics, the following parameters were determined for each sample: (1) soil $\mathrm{pH}$ using a 1:5 soil/water volume ratio, and (2) effective cation exchange capacity (CEC) using a barium chloride $\left(\mathrm{BaCl}_{2}\right)$ solution (HRN ISO 11260:2004).

Element concentrations ( $\mathrm{Cd}, \mathrm{Cr}, \mathrm{Cu}, \mathrm{Fe}, \mathrm{Mn}, \mathrm{Ni}, \mathrm{Pb}$ and $\mathrm{Zn}$ ) in aqua regia soil extracts were determined using inductively coupled plasma optical emission spectroscopy (ICP-OES) on a VistaMP_AX (Varian) (ISO/DIS 22036). All concentrations were calculated on the basis of the dry weight of samples $\left(105^{\circ} \mathrm{C}, 24 \mathrm{~h}\right)$. Mercury concentrations in aqua regia soil extracts were determined using cold-vapour atomic spectrometry (ISO 16772:2004).

Loss on ignition (LOI) as an indicator of organic matter content was determined by gravimetry after dry ashing at 375 ${ }^{\circ} \mathrm{C}$ over $24 \mathrm{~h}$; determinations were performed in duplicate per sample. Organic matter (OM) content was measured and expressed as a percentage using the loss on ignition (LOI) method.

Leaf and bark samples were dried $\left(24 \mathrm{~h}\right.$ at $\left.60{ }^{\circ} \mathrm{C}\right)$ and ground using an inox grinder. Dried plant material was dissolved in a concentrated $\mathrm{HNO}_{3}: \mathrm{H}_{2} \mathrm{O}_{2}(10: 1, \mathrm{v} / \mathrm{v})$ mixture applying the microwave technique on a MARSXpress system (CEM). Element concentrations ( $\mathrm{Cd}, \mathrm{Cr}, \mathrm{Cu}, \mathrm{Fe}, \mathrm{Mn}, \mathrm{Ni}, \mathrm{Pb}$ and $\mathrm{Zn}$ ) were determined by inductively coupled plasma optical emission spectroscopy (ICP-OES Vista MP_AX, Varian).

The statistical analysis was carried out using Statistica v. 10.0 (Statsoft Inc.).

\section{Results}

Results of the aforementioned methods are given in this chapter. Most detailed analysis was performed on soil samples, but basic descriptive statistics and Fe normalization was carried out on bark and leaf samples also.

\subsection{Soil analysis}

Soil analysis included the determination of mineral composition in the investigated area and concentrations of major and trace metals measured in 10 samples in total.

\subsubsection{Mineral composition}

Results of the X-ray diffraction analysis for two separate soil samples (S-6 and S-9) revealed that both samples had quartz as a dominant mineral species with the addition of micaceous and plagioclase minerals.

The principal distinction is in the presence of $14 \AA$ mineral in the first (S-6) and mixed layer minerals in the second (S-9) soil sample.

\subsubsection{Geochemical composition}

Metal concentrations and basic statistical parameters in soil samples of the Prašnik area are shown in Table 1.

The total concentration of major and trace metals for soil samples show relatively higher values for sample S-6 (landmine explosion crater). CEC is almost as twice as high for soil sample S-6 and is mainly not a function of the nature of clay particles, its content in the soil and $\mathrm{pH}$, but more of $\mathrm{OM}$ content and new soil being formed. The landmine explosion opened a lower soil horizon poorer in OM content and created a depression in which OM (litter) can easily be concentrated at its bottom. Samples S-7 to S-10 taken in the deeper forest show that OM is slightly increasing the CEC of the soil but the acidification (lower $\mathrm{pH}$ ) limits it. 
Table 1. Concentrations of major and trace metals $\left(\mathrm{mg} \mathrm{kg}^{-1}\right)$ measured in soil samples of the Prašnik area sampling site with maximum allowed concentrations (MAC) for sandy and silty-loamy soils ( $\left.{ }^{*} \mathrm{NN}, \mathbf{9} / \mathbf{1 4}\right)$

\begin{tabular}{|c|c|c|c|c|c|c|c|c|c|c|c|c|}
\hline $\begin{array}{c}\text { Soil } \\
\text { samples }\end{array}$ & $\begin{array}{c}\text { Cd } \\
\text { mgkg }^{-1}\end{array}$ & $\begin{array}{c}\mathrm{Cr} \\
\mathrm{mgkg}^{-1}\end{array}$ & $\begin{array}{c}\mathrm{Cu} \\
\mathrm{mgkg}^{-1}\end{array}$ & $\begin{array}{c}\text { Fe } \\
\text { mgkg }^{-1}\end{array}$ & $\begin{array}{c}\text { Hg } \\
\text { mgkg }^{-1}\end{array}$ & $\begin{array}{c}\text { Mn } \\
\text { mgkg }^{-1}\end{array}$ & $\begin{array}{c}\mathrm{Ni} \\
\text { mgkg }^{-1}\end{array}$ & $\begin{array}{c}\text { Pb } \\
\text { mgkg }^{-1}\end{array}$ & $\begin{array}{c}\text { Zn } \\
\text { mgkg }^{-1}\end{array}$ & pH & CEC & $\begin{array}{l}\text { LOI } \\
(\%)\end{array}$ \\
\hline S-1 & 0.18 & 27 & 11 & 20040 & 0.07 & 528 & 15 & 17 & 48 & 7.1 & 16 & 6.4 \\
\hline S-2 & 0.08 & 31 & 11 & 23760 & 0.06 & 634 & 16 & 17 & 52 & 7.2 & 18 & 8.2 \\
\hline S-3 & 0.18 & 25 & 9.4 & 20190 & 0.06 & 379 & 15 & 15 & 45 & 6.6 & 15 & 7.2 \\
\hline S-4 & 0.08 & 32 & 10 & 20790 & 0.06 & 414 & 17 & 20 & 46 & 7.0 & 14 & 6.7 \\
\hline S-5 & 0.08 & 28 & 9.4 & 19830 & 0.08 & 425 & 15 & 18 & 48 & 7.2 & 16 & 8.2 \\
\hline S-6 & 0.38 & 57 & 38 & 48360 & 0.08 & 1045 & 50 & 17 & 102 & 7.3 & 29 & 9.0 \\
\hline S-7 & 0.08 & 29 & 8.8 & 20130 & 0.05 & 330 & 14 & 14 & 44 & 7.2 & 15 & 5.8 \\
\hline S-8 & 0.08 & 31 & 9.5 & 21870 & 0.07 & 365 & 14 & 14 & 45 & 5.5 & 16 & 7.6 \\
\hline S-9 & 0.08 & 28 & 11 & 19740 & 0.07 & 514 & 16 & 17 & 47 & 6.3 & 19 & 10.9 \\
\hline S-10 & 0.08 & 29 & 10 & 21540 & 0.08 & 422 & 15 & 17 & 49 & 4.8 & 19 & 10.9 \\
\hline Mean & 0.13 & 32 & 13 & 23625 & 0.07 & 506 & 19 & 17 & 53 & 6.6 & 18 & 8.1 \\
\hline Median & 0.08 & 29 & 10 & 20490 & 0.07 & 423 & 15 & 17 & 47 & 7.1 & 16 & 7.9 \\
\hline Min & 0.08 & 24 & 8.8 & 19740 & 0.05 & 330 & 14 & 14 & 44 & 4.8 & 13 & 5.8 \\
\hline Max & 0.38 & 57 & 38 & 48360 & 0.08 & 1045 & 50 & 20 & 102 & 7.2 & 29 & 11 \\
\hline Low. q. & 0.08 & 28 & 9.4 & 20040 & 0.06 & 379 & 15 & 15 & 45 & 6.3 & 15 & 6.7 \\
\hline Upp. q. & 0.18 & 31 & 10 & 21870 & 0.08 & 527 & 16 & 17 & 49 & 7.2 & 19 & 9.0 \\
\hline St. Dev. & 0.10 & 9.2 & 8.8 & 8779 & 0.01 & 209 & 11 & 1.7 & 17 & 0.83 & 4.4 & 1.7 \\
\hline $\begin{array}{c}\text { MAC* } \\
\text { (sandy soil) } \\
\end{array}$ & $\begin{array}{r}0.0- \\
0.5 \\
\end{array}$ & $0-40$ & $0-60$ & - & $\begin{array}{r}0.0- \\
0.5 \\
\end{array}$ & - & $0-30$ & $0-50$ & $0-60$ & - & - & - \\
\hline $\begin{array}{c}\text { MAC (silty } \\
\text { loamy s.) }\end{array}$ & $\begin{array}{r}0.5- \\
1.0 \\
\end{array}$ & $40-80$ & $60-90$ & - & $\begin{array}{r}0.5- \\
1.0 \\
\end{array}$ & - & $30-50$ & $\begin{array}{l}50- \\
100 \\
\end{array}$ & $\begin{array}{r}60- \\
150 \\
\end{array}$ & - & - & - \\
\hline $\begin{array}{c}\text { MAC (sandy } \\
\text { clay s.) }\end{array}$ & $\begin{array}{r}1.0- \\
2.0 \\
\end{array}$ & $80-120$ & $90-120$ & - & $\begin{array}{r}1.0- \\
1.5 \\
\end{array}$ & - & $50-75$ & $\begin{array}{r}100- \\
150\end{array}$ & $\begin{array}{r}150- \\
200 \\
\end{array}$ & - & - & - \\
\hline
\end{tabular}

The significant Kendall's Tau $(\mathrm{p}<0.05)$ correlations in soil samples were found for $\mathrm{Cd}-\mathrm{Pb}, \mathrm{Cr}-\mathrm{Cu}, \mathrm{Cr}-\mathrm{Fe}, \mathrm{Cr}-\mathrm{Mn}, \mathrm{Cr}-\mathrm{Ni}$, $\mathrm{Cr}-\mathrm{Pb}, \mathrm{Cr}-\mathrm{Zn}$, Cu-Fe, Cu-Mn, Cu-Ni, Cu-Ob, Cu-Zn, Fe-Mn, Fe-Ni, Fe-Pb, Fe-Zn, Mn-No, Mn-Pb and Mn-Zn.

Figure 3 shows logarithmic values of major and trace metal total concentrations for soil samples. Seven of nine analysed elements (Cd, Cr, Cu, Fe, Mn, Ni and Zn) in sample S-6 have higher total concentrations comparing to other analysed samples.

To assess the potential trace metal pollution (e.g. from landmine explosion, river flooding, agricultural activity, traffic, etc.) at the Prašnik sampling site, it was essential to carry out normalization (Oreščanin et al., 2004), which was done using Fe concentration (see Figure 4), loss on ignition (LOI) (see Figure 5), cation exchange capacity (CEC) (see Figure 6) and pH values (see Figure 7) for every site. 


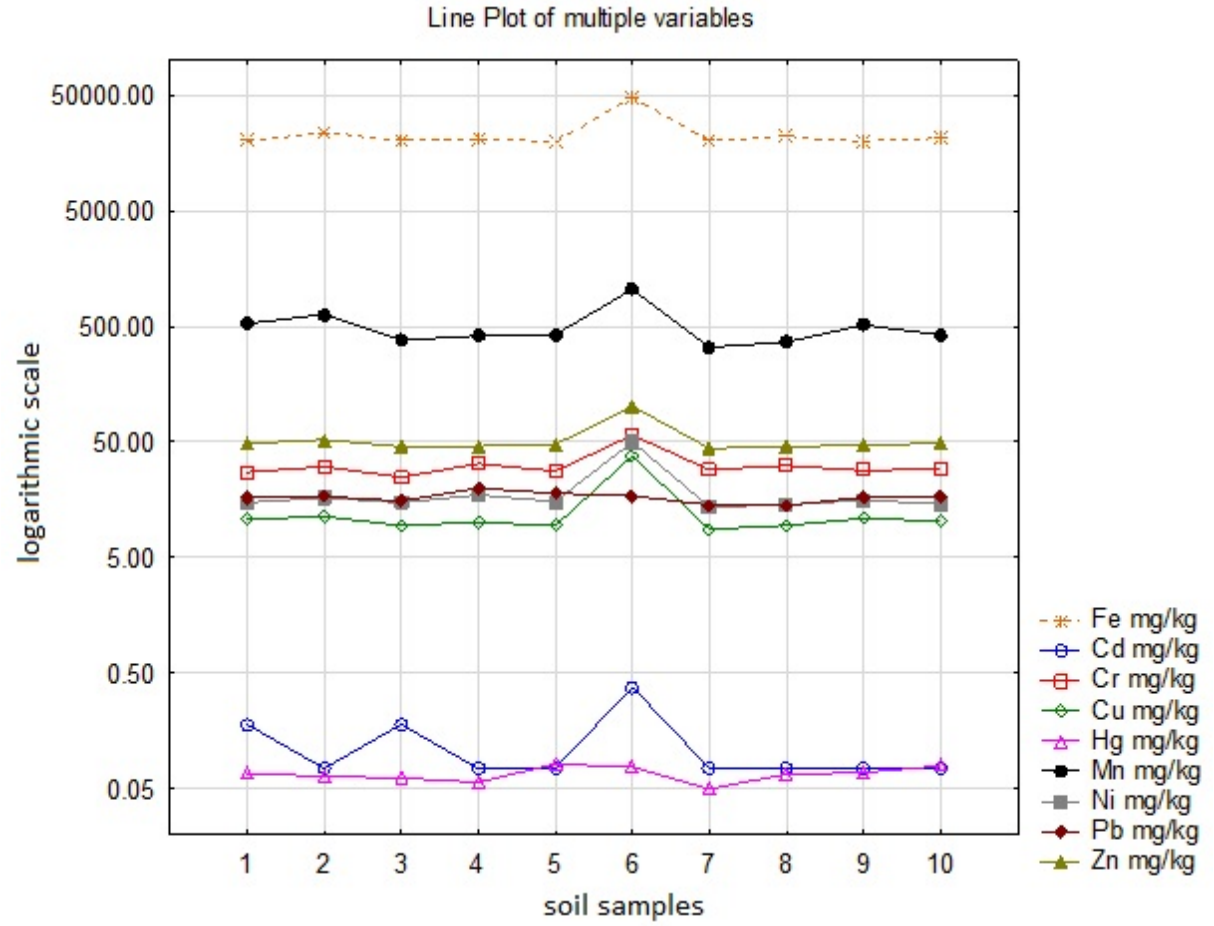

Figure 3: Logarithmic values of major and trace metal total concentrations for soil samples

Normalization using Fe (see Figure 4) as a conservative element not easily influenced by human activity (Blaser, 2000) show only three trace elements (Cd, $\mathrm{Cu}$ and $\mathrm{Ni}$ ) in relatively higher amounts, and a decrease of $\mathrm{Pb}$ and $\mathrm{Hg}$ load at the sample site S-6 (see Figure 4). Total and normalized Pb and Hg concentrations show the highest values for S-4 and S-5, respectively.

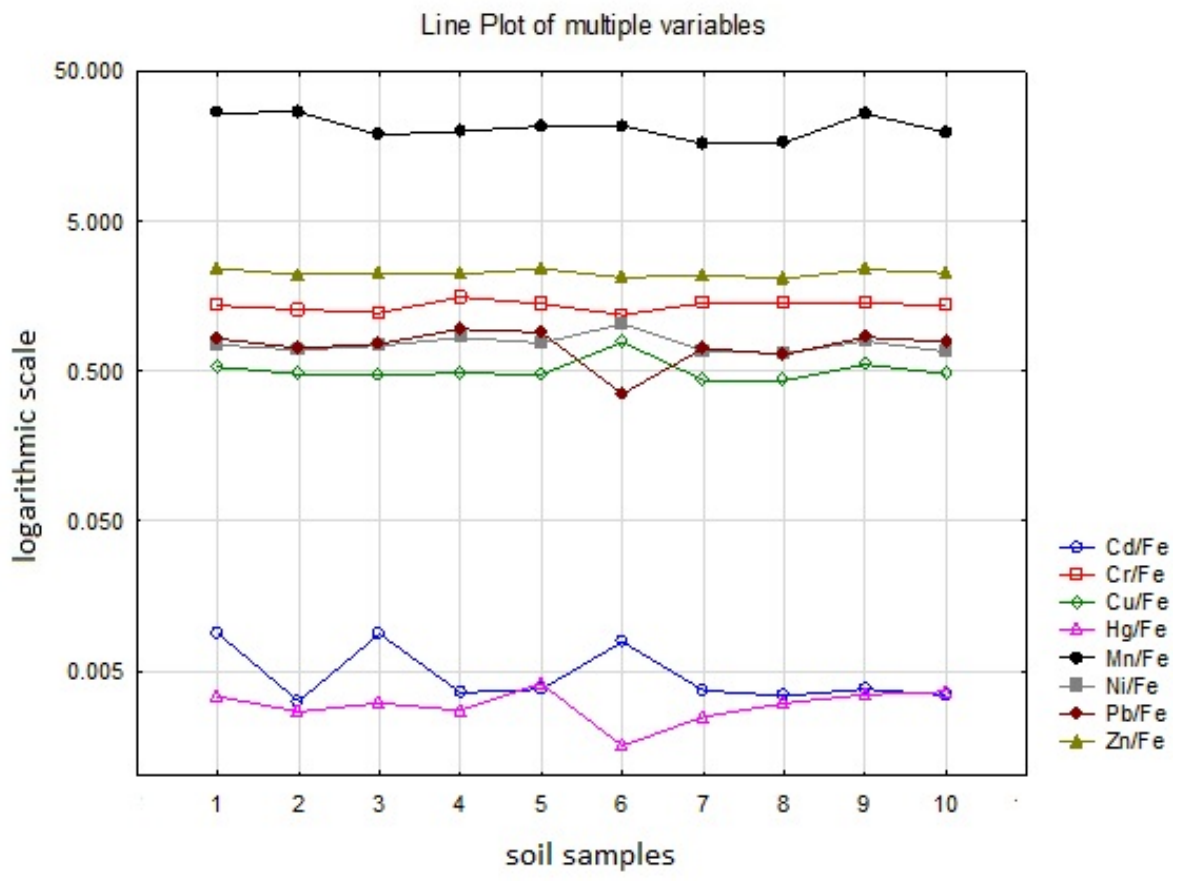

Figure 4: Logarithmic values of major and trace metal normalized concentrations for soil samples (Fe normalization) 


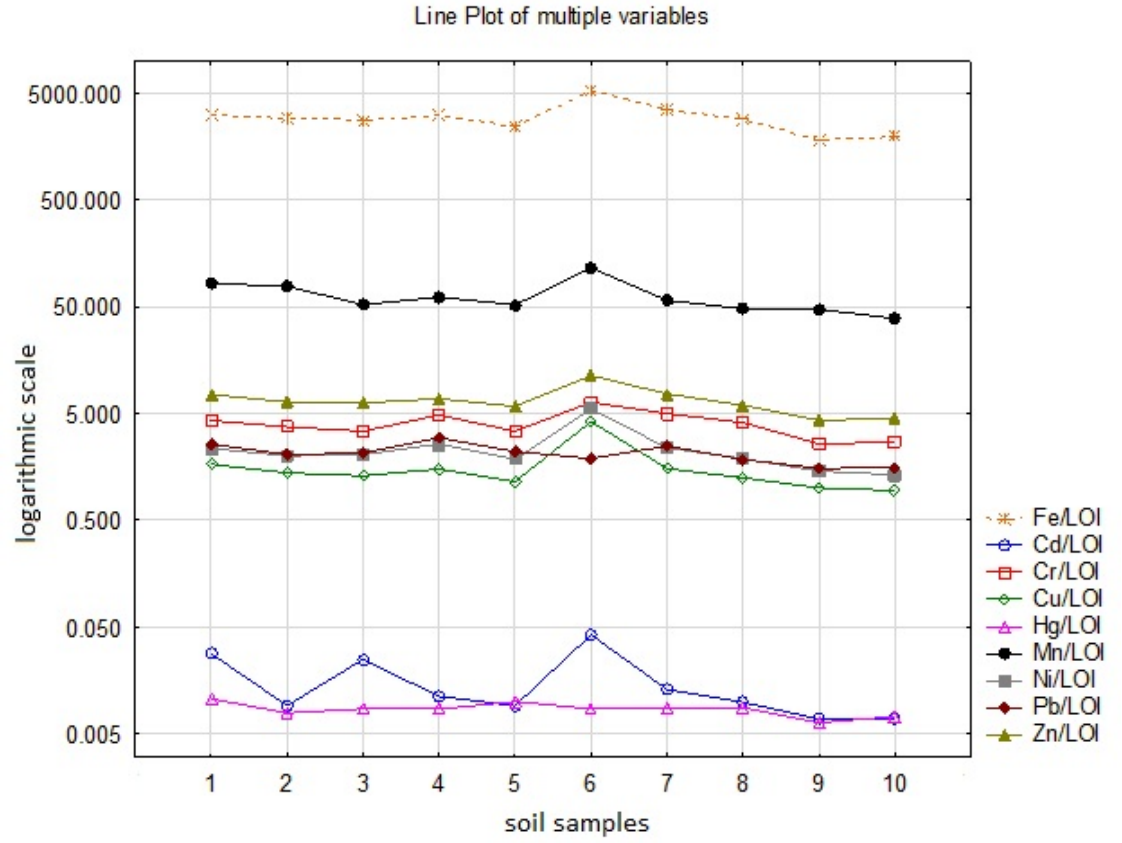

Figure 5: Logarithmic values of major and trace metal normalized concentrations for soil samples (LOI normalization)

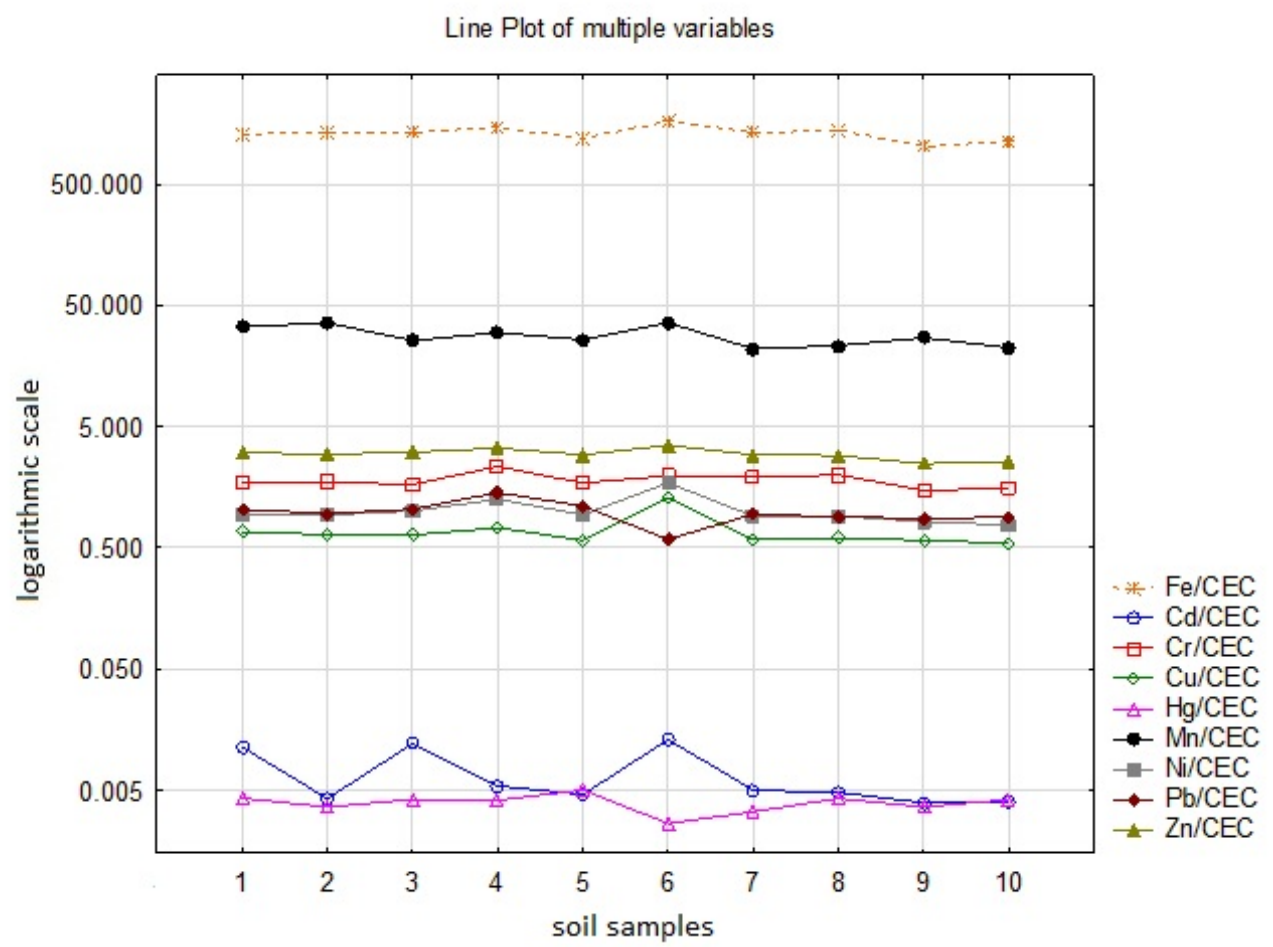

Figure 6: Logarithmic values of major and trace metal normalized concentrations for soil samples (CEC normalization) 


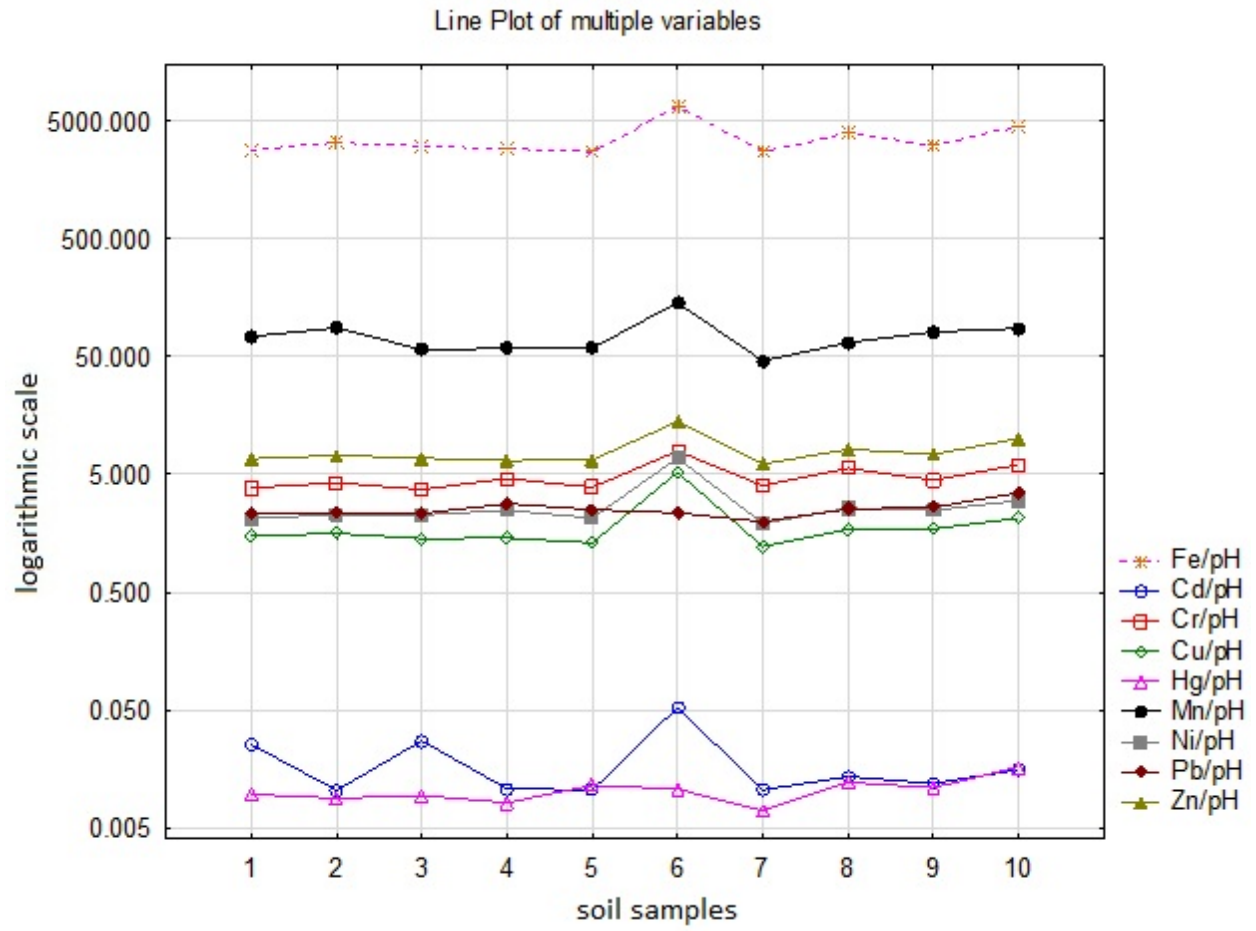

Figure 7: Logarithmic values of major and trace metal normalized concentrations for soil samples (pH normalization).

Using the ratio of concentrations of trace metals for soil samples and 4 normalizing factors such as Fe content, $\mathrm{pH}$, CEC and LOI; slightly higher $\mathrm{Cd}, \mathrm{Cu}$ and $\mathrm{Ni}$ content were observed. Lower $\mathrm{Pb}$, Hg content in soil can be seen for sample S-6 where higher $\mathrm{Cd}, \mathrm{Cu}$ and $\mathrm{Ni}$ content was observed. In addition to soil sample S-6, elevated Cd content was also observed in samples S-1 and S-3. Further examination reveals a possible $\mathrm{Ni}$ and $\mathrm{Cu}$ contamination of soil for sample S-6, which is supported by the examination of normalizing factors. The same Zn concentration peak for sample S-6 was also visible after the normalization with LOI and pH but not with Fe and CEC. Pb shows lower levels for sample S-6 after Fe and CEC normalization, although the LOI and $\mathrm{pH}$ normalization (see Figure 7) shows it in a lesser extent or not at all, respectively. Even though $\mathrm{OM}$ and $\mathrm{pH}$ normalization showed enrichment for seven trace metals (Cd, $\mathrm{Cr}, \mathrm{Cu}, \mathrm{Fe}, \mathrm{Mn}, \mathrm{Ni}$ and $\mathrm{Zn}$ ) at sample site S-6 (see Figures 5 and 7), normalization using Fe and CEC (see Figures $\mathbf{4}$ and 6) reveals only Cd, Cu and Ni in higher content, with the exception of two separate Cd peaks for samples S-1 and S-3. Cr and Zn show higher content with $\mathrm{OM}$ and $\mathrm{pH}$ normalized values but no enrichment or deficiency is visible after Fe and CEC normalization.

Normalized values using $\mathrm{pH}$ for major and trace metals have a general decreasing trend from sample sites S-1 to S-6, at which the load of all metals, but $\mathrm{Hg}$ and $\mathrm{Pb}$, is visibly higher than in the other nine samples. Samples S-7 to S-10 show a general trend of enrichment which can be due to higher OM content, as expected for soils deeper in the forest. OM soil content influences the $\mathrm{pH}$ in the deeper forest parts lowering its value below 5 .

\subsection{Bark analysis}

Tree bark is a good bioindicator of pollution, whether it is exposed to air pollutants directly from the atmosphere (Poikolainen, 1997) or, like in this case, through soil. Due to exposure to pollution, chemical composition of the surface layers of bark changes. It remains in place during an extended period of time and is easily accessible for sampling.

Table 2 shows total concentrations of major and trace metals measured in bark samples. Compared to the concentrations of major and trace metals in soil samples (see Table 1), seven of eight metals have lower concentrations, except for Cd, which is higher in bark samples. 
Table 2. Concentrations of major and trace metals $\left(\mathrm{mg} \mathrm{kg}^{-1}\right)$ measured in bark samples of the Prašnik area sampling site

\begin{tabular}{|c|c|c|c|c|c|c|c|c|}
\hline $\begin{array}{c}\text { Bark } \\
\text { samples }\end{array}$ & $\begin{array}{c}\text { Cd } \\
\mathrm{mg} \mathrm{kg}^{-1}\end{array}$ & $\begin{array}{c}\mathrm{Cr} \\
\mathrm{mg} \mathrm{kg}^{-1}\end{array}$ & $\begin{array}{c}\mathrm{Cu} \\
\mathrm{mg} \mathrm{kg}^{-1}\end{array}$ & $\begin{array}{c}\text { Fe } \\
\mathrm{mg} \mathrm{kg}^{-1}\end{array}$ & $\begin{array}{c}\text { Mn } \\
\text { mg kg }^{-1}\end{array}$ & $\begin{array}{c}\mathrm{Ni} \\
\mathrm{mg} \mathrm{kg}^{-1}\end{array}$ & $\begin{array}{c}\text { Pb } \\
\text { mg kg }^{-1}\end{array}$ & $\begin{array}{c}\mathrm{Zn} \\
\mathrm{mg} \mathrm{kg}^{-1}\end{array}$ \\
\hline B-1 & 0.29 & 0.82 & 5.1 & 153 & 433 & 0.97 & 4.6 & 4.9 \\
\hline B-2 & 0.30 & 0.25 & 6.5 & 84 & 453 & 1.7 & 1.0 & 6.5 \\
\hline B-3 & 0.30 & 0.25 & 8.6 & 149 & 658 & 1.1 & 3.8 & 6.1 \\
\hline B-4 & 0.22 & 0.25 & 4.0 & 128 & 208 & 1.0 & 2.4 & 4.0 \\
\hline B-5 & 0.31 & 0.25 & 5.7 & 82 & 328 & 1.2 & 4.5 & 4.6 \\
\hline B-6 & 0.10 & 0.25 & 4.8 & 70 & 638 & 1.1 & 1.0 & 4.9 \\
\hline B-7 & 0.21 & 0.25 & 5.2 & 119 & 504 & 0.94 & 2.2 & 4.2 \\
\hline B-8 & 1.9 & 0.74 & 6.8 & 183 & 214 & 1.4 & 4.8 & 86 \\
\hline B-9 & 0.24 & 0.25 & 6.1 & 77 & 458 & 1.5 & 3.7 & 5.3 \\
\hline B-10 & 0.48 & 0.57 & 19 & 257 & 44 & 1.3 & 3.5 & 40 \\
\hline "Mean & "0.44 & 0.39 & 7.2 & 130 & 394 & 1.2 & 3.2 & 17 \\
\hline Median & 0.30 & 0.25 & 6.0 & 124 & 443 & 1.2 & 3.6 & 5.1 \\
\hline Min & 0.10 & 0.25 & 4.0 & 70 & 44 & 0.94 & 1.0 & 4.0 \\
\hline Max & 1.9 & 0.82 & 19 & 257 & 658 & 1.7 & 4.8 & 86 \\
\hline Low. q. & 0.22 & 0.25 & 5.1 & 82 & 214 & 1.0 & 2.2 & 4.6 \\
\hline Upp. q. & 0.31 & 0.57 & 6.8 & 153 & 504 & 1.4 & 4.5 & 6.5 \\
\hline St. Dev. & 0.52 & 0.23 & 4.2 & 59 & 196 & 0.24 & 1.4 & 27 \\
\hline
\end{tabular}

Normalized values of trace element concentrations in bark samples (see Figure 8) show sample B-8 to have generally the highest metal content (except for $\mathrm{Mn}, \mathrm{Ni}, \mathrm{Zn}$ and $\mathrm{Pb}$ ). Cd content is lowest for sample B-6 while the Mn content is at its lowest at sample B-10.

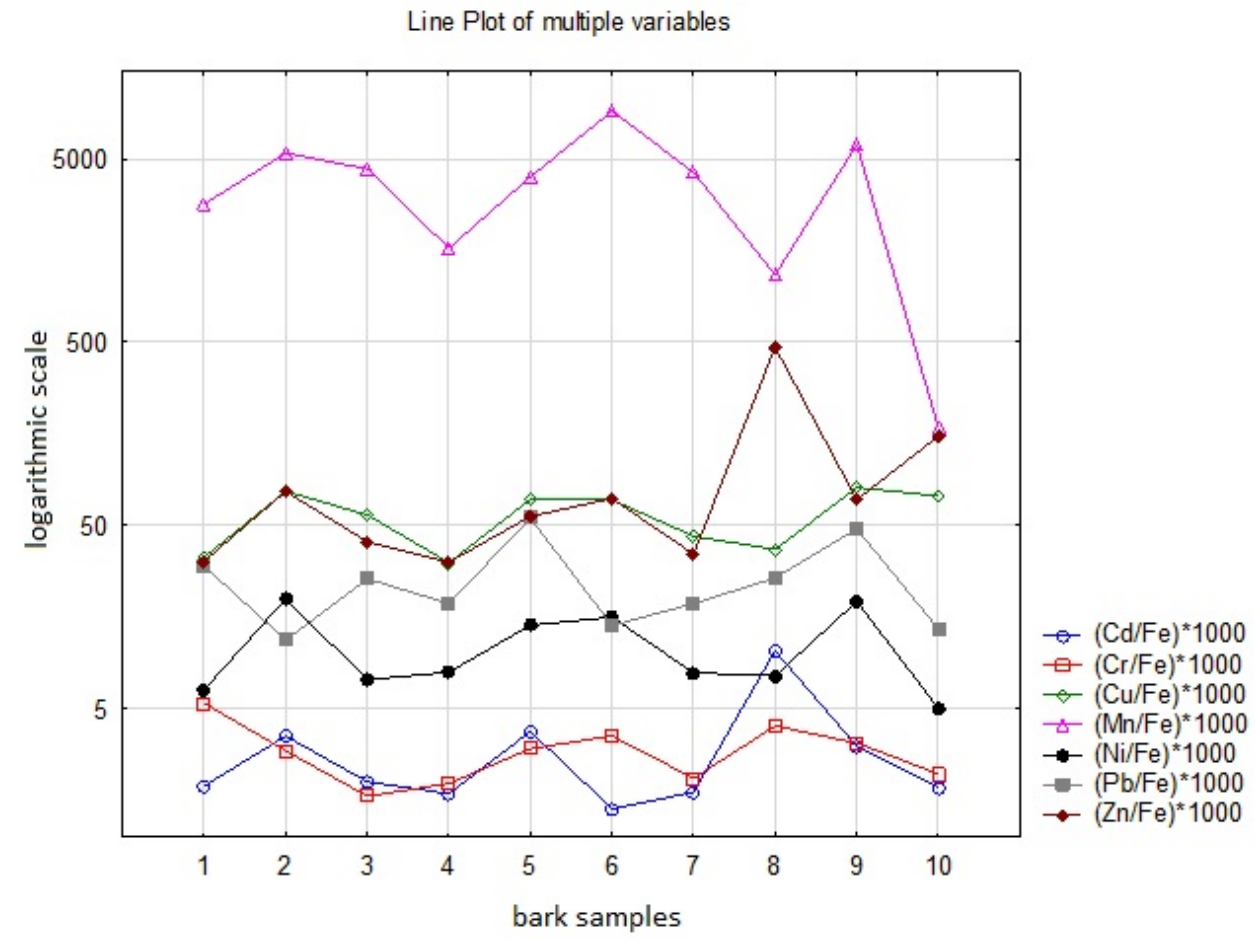

Figure 8: Logarithmic values of major and trace metal normalized concentrations for bark samples (Fe normalization)

The significant Kendall's Tau ( $<<0.05$ ) correlations of Cd-Cr, Cd-Pb, Cd-Zn, Cr-Fe, Cu-Zn, Ni-Zn and Zn-Pb suggest a common source for analysed metals. 


\subsection{Leaf analysis}

Soil contamination generally has a negative influence on the nearby vegetation. Plants are known for the accumulation of major and trace metals from contaminated soil, therefore detection in bark and leaves samples (see Table 3) was expected.

Table 3. Concentrations of major and trace metals $\left(\mathrm{mg} \mathrm{kg}^{-1}\right)$ measured in leaf samples of the Prašnik area sampling site

\begin{tabular}{|c|c|c|c|c|c|c|c|c|}
\hline $\begin{array}{c}\text { Leaf } \\
\text { samples }\end{array}$ & $\begin{array}{c}\text { Cd } \\
\text { mg kg-1 }^{-1}\end{array}$ & $\begin{array}{c}\mathrm{Cr} \\
\mathrm{mg} \mathrm{kg}^{-1}\end{array}$ & $\begin{array}{c}\mathrm{Cu} \\
\mathrm{mg} \mathrm{kg}^{-1}\end{array}$ & $\begin{array}{c}\text { Fe } \\
\mathrm{mg} \mathrm{kg}^{-1}\end{array}$ & $\begin{array}{c}\mathrm{Mn} \\
\mathrm{mg} \mathrm{kg}^{-1}\end{array}$ & $\begin{array}{c}\mathrm{Ni} \\
\mathrm{mg} \mathrm{kg}^{-1}\end{array}$ & $\begin{array}{c}\mathrm{Pb} \\
\mathrm{mg} \mathrm{kg}^{-1}\end{array}$ & $\begin{array}{c}\mathrm{Zn} \\
\mathrm{mg} \mathrm{kg}^{-1}\end{array}$ \\
\hline L-1 & 0.10 & 0.89 & 7.8 & 123 & 1045 & 4.4 & 1.0 & 20 \\
\hline L-2 & 0.10 & 0.68 & 5.3 & 223 & 1475 & 3.7 & 1.0 & 20 \\
\hline L-3 & 0.10 & 0.25 & 5.8 & 159 & 951 & 3.5 & 1.0 & 26 \\
\hline L-4 & 0.10 & 0.80 & 5.5 & 367 & 458 & 5.6 & 1.0 & 24 \\
\hline L-5 & 0.10 & 0.25 & 9.9 & 88 & 710 & 4.2 & 1.0 & 20 \\
\hline L-6 & 0.24 & 0.25 & 8.7 & 211 & 1019 & 4.2 & 1.0 & 25 \\
\hline L-7 & 0.10 & 0.52 & 5.8 & 197 & 996 & 3.8 & 1.0 & 26 \\
\hline L-8 & 0.10 & 0.64 & 5.4 & 234 & 641 & 2.9 & 1.0 & 20 \\
\hline L-9 & 0.28 & 0.51 & 5.6 & 162 & 1129 & 0.30 & 1.0 & 68 \\
\hline L-10 & 0.78 & 0.62 & 7.0 & 185 & 812 & 0.30 & 1.0 & 62 \\
\hline "Mean & 0.20 & 0.54 & "6.7 & 195 & 924 & 3.3 & $\bar{~} 1.0$ & 31 \\
\hline Median & 0.10 & 0.57 & 5.8 & 191 & 973 & 3.8 & 1.0 & 25 \\
\hline Min & 0.10 & 0.25 & 5.3 & 88 & 458 & 0.30 & 1.0 & 20 \\
\hline Max & 0.78 & 0.89 & 9.9 & 367 & 1475 & 5.6 & 1.0 & 68 \\
\hline Low. q. & 0.10 & 0.25 & 5.5 & 159 & 710 & 2.9 & 1.0 & 20 \\
\hline Upp. q. & 0.24 & 0.68 & 7.8 & 223 & 1045 & 4.2 & 1.0 & 26 \\
\hline St. Dev. & 0.21 & 0.23 & 1.6 & 75 & 285 & 1.7 & 1.0 & 18 \\
\hline
\end{tabular}

Median values of $\mathrm{Cd}, \mathrm{Cr}, \mathrm{Cu}, \mathrm{Fe}, \mathrm{Mn}, \mathrm{Ni}, \mathrm{Pb}$, and $\mathrm{Zn}$ in leaf samples have higher values compared to bark samples for five trace metals (Cr, Fe, Mn - double, Ni and Zn). Compared to the soil samples, only Cd and Mn (again double) have higher concentrations in leaf samples. Table 3 shows that the lowest concentration among all metals observed in leaf samples is of Cd (except L-10). The significant Kendall's Tau $(\mathrm{p}<0.05)$ correlations in leaf samples were found only for $\mathrm{Cd}-\mathrm{Zn}$ and $\mathrm{Cu}-\mathrm{Fe}$.

Normalized values of trace element concentrations in leaf samples (see Figure 9) show L-4 to have the lowest content, except for $\mathrm{Cr}$ and $\mathrm{Ni}$. Cr content is lowest for L-6, while Ni content is at its lowest at L-9 and L-10. 


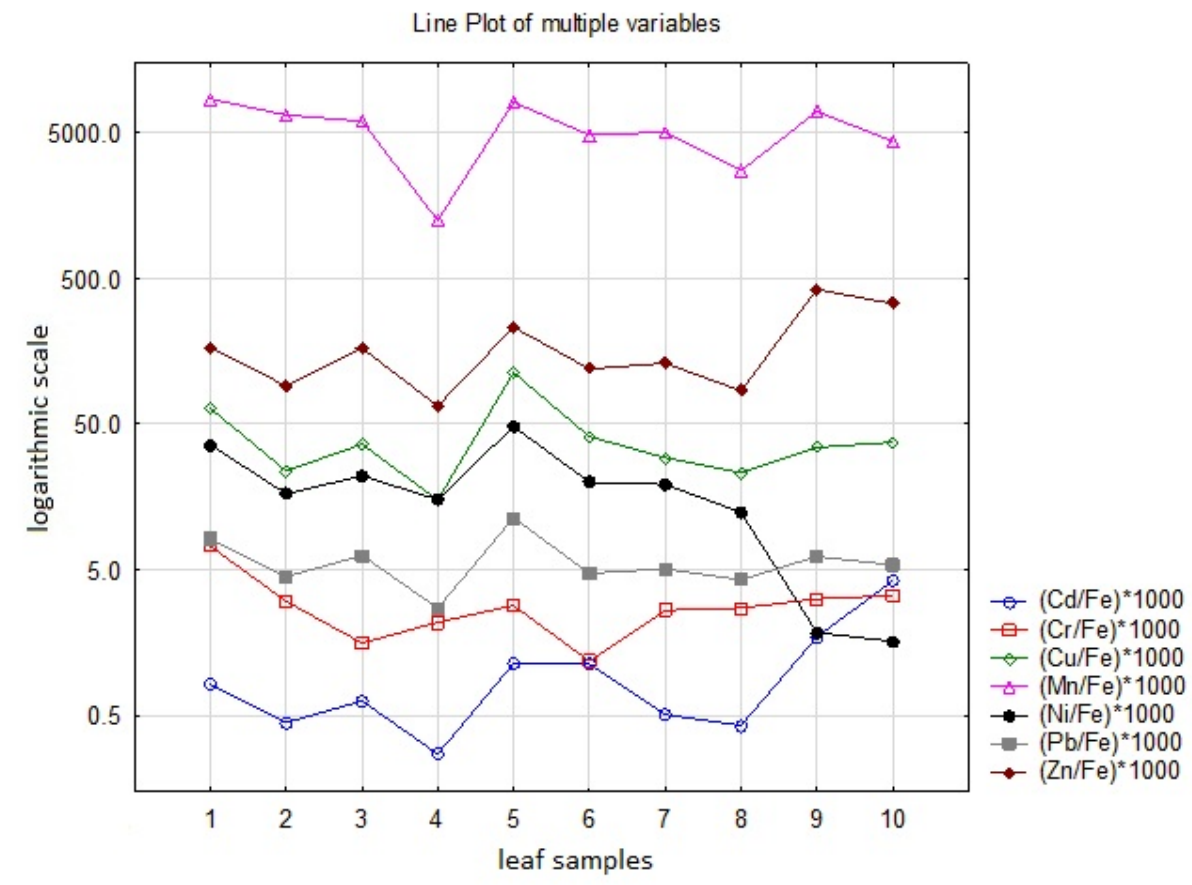

Figure 9: Logarithmic values of major and trace metal normalized concentrations for leaf samples (Fe normalization)

\section{Discussion}

The occurrence of minerals obtained by the X-ray diffraction analysis is in accordance with the exposed rock types of the surrounding rock masses of the north Dinarides and Psunj granite-metamorphic complex, and can be explained as a consequence of weathering, transport and deposition processes.

The majority of trace elements found in soils are either in the proposed interval, or well bellow the minimum value of the specific range when compared to the concentrations from the Geochemical Atlas of the Republic of Croatia (Halamić et al., 2009). Only in the case of $\mathrm{Cu}, \mathrm{Mn}, \mathrm{Ni}$ and $\mathrm{Zn}$ the highest values (S-6) are above the maximum threshold of the proposed interval, where $\mathrm{Ni}$ is only $2 \mathrm{mg} \mathrm{kg}^{-1}$ above the interval.

Cd concentrations for all but soil sample S-6 fall within the observed concentrations for uncontaminated soils (KabataPendias, 2011). The mean value of $C d$ in soil samples $\left(0.13 \mathrm{mg} \mathrm{kg}^{-1} \pm 0.10 \mathrm{SD}\right.$, Table 1$)$ is below the world average soil concentration which is estimated as $0.41 \mathrm{mg} \mathrm{kg}^{-1}$. The maximum value $\left(0.38 \mathrm{mg} \mathrm{kg}^{-1}\right)$ has been measured for sample S-6, which is four to five times greater than the minimum value of $\mathrm{Cd}$ measured for soil samples. According to KabataPendias (2011), apparently all values of $\mathrm{Cd}$ in topsoil, which are higher than the measured background values, are a result of anthropogenic activity.

$\mathrm{Cd}$ and Zn are chemically similar and interact negatively in the soil (Gupta \& Potalia, 1990), therefore an adequate concentration of $\mathrm{Zn}$ in the soil would cause a decrease of Cd plant uptake. The maximum Cd concentration $\left(0.78 \mathrm{mg} \mathrm{kg}^{-}\right.$ ${ }^{1}$ ) for leaf samples is five to seven times higher than the mean concentrations for Quercus ilex L. leaves reported by De Nicola et al., 2008 and 2013 study, but the mean is closest to the urban unwashed leaf sample of $0.15 \mathrm{mg} \mathrm{kg}^{-1}$.

Hg mean concentration $\left(0.07 \mathrm{mg} \mathrm{kg}^{-1} \pm 0.01 \mathrm{SD}\right.$, Table 1) corresponds to the average concentration $\left(0.08 \mathrm{mg} \mathrm{kg}^{-1}\right)$ measured for same top soils in Slovakia and for the world soil average $\left(0.07 \mathrm{mg} \mathrm{kg}^{-1}\right)$. As a potentially toxic metal it poses a threat to plant and animal life (Driscoll et al., 1994). Hg is usually concentrated in topsoil and is easily absorbed by roots after which it is translocated to leaves and other parts of the plant. In acidified soils, Hg is readily adsorbed to OM where it is bound to organic complexes thus decreasing its leaching (Kabata-Pendias, 2011). Elevated total Hg content for samples S-5, S-6 and S-10 could be explained by the high organic matter content as it usually forms strong bonds with OM creating organomercury compounds/complexes (Kabata-Pendias, 2011; Sawidis, 2010). 
When comparing $\mathrm{Pb}, \mathrm{Cu}$ and $\mathrm{Zn}$ values to the soil concentrations measured at a depth of 6-30 $\mathrm{cm}$, in a similar type of biocenosis (Quercus robur L. and Carpino betuli L.) from Western Croatia (Vrbek \& Pilaš, 2004), there are some major differences for $\mathrm{Zn}$ and $\mathrm{Cu}$. The range of the total $\mathrm{Pb}$ concentrations measured for the Prašnik rainforest sampling area 14-20 $\mathrm{mg} \mathrm{kg}-1$, are comparable with the range of 14 to $22 \mathrm{mg} \mathrm{kg}^{-1}$ established in the forests of the Pokupsko basin. The average Zn level from the Pokupsko basin (Repaš area) is 3.6 times smaller than the maximum Zn concentration for the similar horizon in the Prašnik sampling site, although only approximately 2 times (1.86) smaller than the second highest $\mathrm{Zn}$ value in Prašnik. The same area of the Pokupsko basin has the highest average $\mathrm{Cu}$ value $\left(11 \mathrm{mg} \mathrm{kg}^{-1}\right)$ in the same horizon (II horizon, 6-30 cm) and is comparable with the levels in Prašnik which range from 8.8 to $11 \mathrm{mg} \mathrm{kg}^{-1}$, if sample S-6 from Prašnik is excluded $\left(38 \mathrm{mg} \mathrm{kg}^{-1}\right)$.

Comparing total concentrations of metals to maximum allowed concentrations (MAC) of soil for agricultural use in Croatia (NN, 9/14) it can be seen that $\mathrm{Cd}, \mathrm{Cu}, \mathrm{Hg}$, and $\mathrm{Pb}$ levels are below proposed MAC values for sandy soil and well below for silty loamy soils. The exceptions are $\mathrm{Cr}$, $\mathrm{Ni}$ and $\mathrm{Zn}$ concentrations which are in the MAC range for silty loamy soils and are in accordance with the prevailing soil type (pseudogley) in the sampling area. As Mn is not considered as a polluting metal (Kabata-Pendias, 2011) there is no MAC value proposed by Croatian legislative (NN, 9/14). Nevertheless, MAC value for $\mathrm{Mn}$ for agricultural soils is estimated at a range of 1500-3000 $\mathrm{mg} \mathrm{kg}^{-1}$ (Kabata-Pendias, 2011) which is much higher than the highest measured concentration $\left(1045 \mathrm{mg} \mathrm{kg}^{-1}\right)$. Cu values also do not exceed the MAC values frequently cited in literature which range from 20-100 mg/kg and are well below the German precautionary values for clayey (100 $\mathrm{mg} \mathrm{kg}^{-1}$ ) and loamy (60 mg kg-1) soils (Kabata-Pendias, 2011). Pb values (14-20 mg kg-1) do not exceed several proposed upper limits for unpolluted soils (56, 60, $70 \mathrm{mg} \mathrm{kg}^{-1}$ ) and are below the estimated overall mean for different soils $\left(27 \mathrm{mg} \mathrm{kg}^{-1}\right)$. Almost all $\mathrm{Ni}$ concentrations (14-50 mg kg-1) measured correspond to the range of mean concentrations reported for several countries (13-37 $\mathrm{mg} \mathrm{kg}^{-1}$ ) with an exception of sample S-6.

The mean value of $\mathrm{Zn}$ in soil (53 \pm 17 SD, Table 1) did not exceed the maximum allowed concentrations (MAC) for sandy clay soils and was even below maximum allowed value for sandy soils (NN 9/14). The maximum value (102 $\left.\mathrm{mg} \mathrm{kg}^{-1}\right)$ was measured in the sample S-6 which is above the values for most type of soils, but is still in the normal range for sandy clay soil according to the national MAC values. Zn concentrations (44-102 mg kg-1) are generally within the range of mean content for different soil groups in several European countries (7-89 $\left.\mathrm{mg} \mathrm{kg}^{-1}\right)$.

Hg concentrations do not exceed the MAC range for sandy soil according to the Croatian legislative (NN, 9/14) and pose no health concern for flora or fauna of Prašnik. Maximum concentration is measured for the sample site S-5 with site S-10 and S-6 as second and third highest (see Table 1), respectively.

As high concentration ratios are not neccesarily an indication of contamination or pollution and can be the result of a normalizing factor decrease, it was neccesary to examine the values that comprise the ratio (Daskalakis \& O'Connor, 1995). Cd enrichment is most plausibly a result of some kind pollution which could also be an landmine explosion or other sincethe normalizing factors do not decrease for samples S-1, S-3 and S-6.

Elevated $\mathrm{Pb}$ content is known to be elevated in soils at military shooting ranges, as ammunition and explosive devices are partly made of $\mathrm{Pb}$ (Chappell, 2011). Even so, depletion is visible for $\mathrm{Pb}$ and $\mathrm{Hg}$ for sample S-6 after Fe and CEC normalization. $\mathrm{Pb}$ and $\mathrm{Hg}$ readily make organic complexes and bond with organic matter and are usually associated with higher OM content (Kabata-Pendias, 2011), which in this case is not evident. However, the lack of enrichment of normalized $\mathrm{Pb}$ and $\mathrm{Hg}$ concentrations in S-6 could be a result of metals such as $\mathrm{Pb}$ being partly present in a bioinaccessible form, indicating its anthropogenic origin.

Only $\mathrm{Ni}, \mathrm{Cu}$ and $\mathrm{Cd}$ were found to have peaks for the same samples after each normalization which indicates that their enrichment is not due to only natural processes.

\section{Conclusion}

Results of this research work have revealed that there is evident enrichment of soil by $\mathrm{Cd}, \mathrm{Cu}$ and $\mathrm{Ni}$ trace metals at the Prašnik rainforest sampling site. This is especially noticeable for soil sample S-6, a landmine explosion crater, which has higher concentrations of $\mathrm{Cd}, \mathrm{Cr}, \mathrm{Cu}, \mathrm{Fe}, \mathrm{Mn}$ and $\mathrm{Ni}$ compared to all other sampling sites. Levels of metals in the bark are well associated with the metal concentrations in the soil, reflecting the close relationships between soil pollution and its accumulation in the bark. Somewhat higher total concentrations of seven major and trace metals in soil are not of any health concern to the Prašnik rainforest flora and fauna. Concentrations fit within the specified values for soils being used for agricultural purposes and are within the expected range of the geochemical map of Croatia in the Geochemical Atlas of the Republic of Croatia. 
Results of normalization using Fe, CEC, LOI and pH showed elevated values for the same samples only for Cd, $\mathrm{Cu}$ and $\mathrm{Ni}$. Given results indicate that their enrichment is not a natural occurence, but rather related to human activity, such as the explosion of a landmine. This is to be expected due to the war that was fought in Croatia 23 years ago and that samples were taken near the "danger mine" sign. Generally positive statistically significant Kendall's Tau correlation coefficients of major and trace metals also indicate that the war activity played a certain role in the distribution pattern of soil and adjacent vegetation.

Acknowledgement: The third co-author (G.M.) is grateful to Đuka Kurelac and Josip Mikšić, who were generously willing to participate and offer invaluable help during the field work in the December 2013, when the terrain was dangerous to visit due to landmines.

\section{References}

Aksoy, A., Sahin, U. \& Duman, F. (2000): Robinia pseudo-acacia L. as a possible biomonitor of heavy metal pollution in Kayseri, Turkish Journal of Botany, 24 (5), 279-284.

Bašić, F. (2013): The Soils of Croatia, World Soil Book Series, International Union of Soil Sciences. In: Hartemink, A.E. (ed), Springer Verlag, 142-144, $179 \mathrm{p}$.

Berhe, A.A. (2007): The Contribution of Landmines to Land Degradation, Land Degradation and Development, 18 (1), 1-15.

Blaser, P., Zimmermann, S., Luster, J. \& Shotyk, W. (2000): Critical examination of trace element enrichments and depletions in soils: As, Cr, Cu, Ni, Pb, and Zn in Swiss forest soils, Elsevier, Science Direct, Science of the Total Environment, 249, 257280.

Bogunović, M., Vidaček, Ž., Racz, Z., Husnjak, S., Špoljar, A., Sraka, M.: FAO/Unesco Croatian soil map, small scale 1:1000000, University of Zagreb, Faculty of Agriculture, project Monitoring Agriculture with Remote Sensing (1998).

Buser, S., Ramovs, A., Drovenik, M. \& Pleničar, M. (1989): Geological setting of Slovenia. In: Encyclopedia of Slovenia, 3rd edn. Mladinska knjiga, Ljubljana, 195-203.

Chappel, M.A., Price, C.L. \& George, R.D. (2011): Environmental chemistry of Explosives and Propellant Compounds in Soils and Marine Systems: Distributed Source Characterization and Remedial Technologies, volume 1069, ACS Symposium Series; American Chemical Society: Washington, DC, Oxford University Press, Inc.

Daskalakis, K.D. \& O’Connor, T.P. (1995): Normalization and Elemental Sediment Contamination in the Coastal United States, Environ. Sci. Technol., 29 (2), 470-477.

De Nicola, F., Maisto, G., Prati, M. V. \& Alfani, A. (2008): Leaf accumulation of trace elements and polycyclic aromatic hydrocarbons (PAHs) in Quercus ilex L., Elsevier, Science Direct, Environmental Pollution, 153, 376-383.

De Nicola, F., Spagnuolo, V., Baldantoni, D., Sessa, L., Alfani, A., Bargagli, R., Monaci, F., Terracciano, S. \& Giordano, S. (2013): Improved biomonitoring of airborne contaminants by combined use of holm oak leaves and epiphytic moss, Elsevier, Chemosphere, 92(9) 1224-1230.

Driscoll, C.T., Otton, J.K., \& Iverfeldt, Å. (1994): Trace Metal Speciation and Cycling, In: Moldan B. and Cerny J. (eds.): Biochemistry of Small Catchments: A tool for environmental research, SCOPE, John Wiley and Sons Ltd., 299-322, 409 p.

Ernst, W.H.O. (1990): Mine vegetation in Europe, Heavy metal tolerance in plants: Evolutionary aspects, A. J. Shaw, ed., CRC, Boca Raton, Fla., 21-51.

Ernst, W.H.O. (1995): Decontamination or consolidation of metalcontaminated soils by biological means, Heavy metals: Problems and solutions, W. Salomons, U. Forstner, and P. Mader, eds., Springer, Berlin, 141-149.

Fantozzi, F., Monaci, F., Blanusa, T. \& Bargagli, R. (2013): Holm Oak (Quercus ilex L.) canopy as interceptor of airborne trace elements and their accumulation in the litter and topsoil, Elsevier, Science Direct, Environmental Pollution, 183, 89-95.

Godbold, D. L., Tischner, R. \& Huttermann, A. (1987): Effects of heavy metals and aluminium on the root physiology of Spruce (Picea abies [L.] Karst) seedlings. U: Hut-chinson, T.C., Meema, K.M. (eds): Effects of atmospheric pollutants on forest, wetlands and agricurtural ecosystems, NATO ASI Series G 16, 387-400, Springer-Verlag, Berlin.

Gupta, V.K. \& Potalia, B.S. (1990): Zinc-cadmium interaction in wheat, Journal of the Indian Society of Soil Science, 38, $452-457$.

Halamić, J. \& Miko, S. (eds) (2009): Geochemical Atlas of the Republic of Croatia-Croatian Geological Survey, Zagreb, 87 p.

HRN ISO 11260 (2004): Soil Quality - Determination of Effective Cation Exchange Capacity and Base Saturation Level Using Barium Chloride Solution (ISO 11260:1994+Cor 1:1996).

Husnjak, S. (2014): Sistematika tala Hrvatske (Systematics of soils in Croatia), Hrvatska sveučilišna naklada, Tiskara Zelina d.d., Zagreb, 373 p. (in Croatian) 
ISO 16772 (2004): Soil quality - Determination of mercury in aqua regia soil extracts with cold-vapour atomic spectrometry or coldvapour atomic fluorescence spectrometry.

ISO/DIS 22036: Soil quality - Determination of trace elements in extracts of soil by inductively coupled plasma-atomic emission spectrometry (ICP-AES).

Kabata-Pendias, A., (2011): Trace Elements in Soils and Plants, fourth ed. CRC Press, Taylor and Francis Group, LLC, Boca Raton, USA, 505 p.

Kim, K.-H. \& Kim, S.-H. (1999): Heavy metal pollution of agricultural soils in central regions of Korea, Wat. Air. Soil. Pollut., 111, 109-122.

Lucaciu, A., Frontasyeva, M.V., Steinnes, E., Cheremisina, Ye.N., Oprea, C., Progulova, T.B., Staicu, L. \& Timofte, L. (1999): Atmospheric deposition of heavy metals in Romania studied by the moss biomonitoring technique employing nuclear and related analytical techniques and GIS technology, Journal of Radioanalytical and Nuclear Chemistry, 240 (2), 457-458.

Matić, S., Prpić B., Rauš, Đ., \& Vranković, A. (1979): Rezervati šumske vegetacije Prašnik i Muški bunar, studija ekološko-uzgojnih osobina (Prašnik and Muški bunar forest reserves, study of ecological-breeding features), Šumsko gospodarstvo „Josip Kozarac“, Nova Gradiška, 131 p. (in Croatian)

Mesić, I., Balen, D., Romić, M., Medunić, G., Bakić, H., Kampić, Š. \& Šoštarko, K. (2014): Trace metal contamination of the Prašnik rain forest soil as a consequence of the war legacy, BIOGEOMON, 8th International Symposium on Ecosystem Behavior, Bayreuth, Germany, July $13-17$.

Narodne novine br. 9/14. Pravilnik o zaštiti poljoprivrednog zemljišta od onečišćenja (Regulations on Agricultural Land Protection against Pollution), Narodne novine d.d., Zagreb. (in Croatian)

Oreščanin, V., Lulić, S., Pavlović, G. \& Mikelić, L. (2004): Granulometric and chemical composition of the Sava River sediments upstream and downstream of the Krsko nuclear power plant, Environmental Geology, 46 (5), 605-613.

Poikolainen, J. (1997): Sulphur and heavy metal concentrations in scots pine bark in northern Finland and the Kola Peninsula, Water, Air and Soil Pollution, 93(1), 395-408.

Romić, M. (2012): Bioavailability of trace metals in terrestrial environment: Methodological issues, European Chemical Bulletin, 1(11), 489-493.

Sawidis, T., Breuste, J., Mitrović, M., Pavlović, P. \& Tsigaridas, K. (2011): Trees as bioindicator of heavy metal pollution in three European cities, Elsevier, Science Direct, Environmental Pollution, 159, 3560-3570.

Stanišić, S.M., Ignjatović Lj.M., Anđelković, I., Stević, M.C., Tasić, A.M. \& Savić Biserčić, M. (2012): Ultrasound-assisted extraction of matrix elements and heavy metal fractions associated with Fe, Al and Mn oxyhydroxides from soil, Journal of the Serbian Chemical Society, 77 (9), 1287 - 1300.

Šikić, K., Basch, O. \& Šimunić, A. (1979): Geology of Zagreb Sheet (L38-80), Basic geological map of Yugoslavia, 1:100000, Institute of Geology, Zagreb, Beograd (Federal institute of Geology) (in Croat., Engl. Summary).

Šparica, M., Buzaljko, R. \& Jovanović, Č. (1984): Geology of Nova Gradiška Sheet (L33-107). Basic geological map of Yugoslavia, 1:100000. Institute of Geology, Zagreb, Institute of Geology, Sarajevo, Beograd (Federal institute of Geology) (in Croat.).

Vidosavljević, D., Puntarić, D., Gvozdić, V., Jergović, M., Jurčev-Savičević, A., Puntarić, I., Puntarić, E. \& Vidosavljević, M. (2014): Trace Metals in the Environment and Population as Possible Long Term Consequence of War in Osijek-Baranja County, Croatia, Collegium Antropologicum, 38, 925-931.

Vrbek, B. \& Pilaš, I. (2004): Teške kovine ( $\mathrm{Pb}, \mathrm{Cu}$ i $\mathrm{Zn}$ ) u tlu šume hrasta lužnjaka i običnoga graba (Carpino betuli-Quercetum roboris) sjeverozapadne Hrvatske (Heavy metals ( $\mathrm{Pb}, \mathrm{Cu}$ and $\mathrm{Zn}$ ) in the soil of penducled oak and common hornbeam forest in north-west Croatia), Rad. Šumar. inst. 39 (2): 169-184. (in Croatian)

Zimmerman, A.J. \& Weindorf, D.C. Heavy metal and trace metal analysis in soil by sequential extraction: a review of procedures. Int. J. Anal. Chem. 2010, doi:10.1155/2010/387803 


\section{Sažetak}

Tragovi metala u tlu, kori i lišću kao posljedica ratnih zbivanja (primjer prašume Prašnik, Hrvatska)

Prašuma Prašnik kao poseban rezervat šumske vegetacije visoko je zaštićeno područje, ali ne samo zbog jedinstvenoga sastava drveća, već zahvaljujući i geografskomu položaju te u određenoj mjeri povijesnim zbivanjima. Nalazi se na lijevoj obali rijeke Save, oko $3 \mathrm{~km}$ sjeverno od Nove Gradiške. Područje istraživanja pripada jugozapadnomu dijelu Panonskoga bazenskog sustava, području Savske depresije. Cilj ovoga istraživanja bio je procijeniti mogući utjecaj ratnih zbivanja u Hrvatskoj (od prije 23 godine), kada je ovo područje minirano, i utvrditi koncentracije metala. Deset uzoraka tla nasumično je prikupljeno zajedno $s$ korom i lišćem. Koncentracije glavnih metala i metala u tragovima mjerene su za sve 3 grupe uzoraka ICP metodom. Analizirano tlo sastoji se od kvarca, tinjčastoga minerala, minerala $14 \AA$, plagioklasa i mješovitoga sloja minerala. Sve vrijednosti metala u uzorcima uzetim iz nekadašnjega minskog kratera veće su $2-4$ puta u odnosu na ostale. Statističkom analizom dobiveni su pozitivni, statistički značajni Kendallovi tau-koeficijenti korelacije tragova metala $(\mathrm{Cd}, \mathrm{Cr}, \mathrm{Cu}, \mathrm{Ni}, \mathrm{Zn})$ i za sve kombinacije uzoraka tla, lišća i kore. Takvi rezultati upućuju na to da je ratna aktivnost odigrala određenu ulogu u distribucijskome uzorku tla i vegetativnim razinama metala u tragovima.

\section{Ključne riječi}

glavni metali, metali u tragovima, rat, zaštićeno područje, Prašnik 